\title{
STUDI AWAL PEMANFAATAN EKSTRAK WARNA TANAMAN TARUM (Indigofera tinctoria) SEBAGAI DYE UNTUK DSSC
}

\author{
Iswadi I Patunrengi ${ }^{1 *}$, Aisyah ${ }^{2}$, A Nasyori $^{3}$, Awaluddin I Perdana ${ }^{4}$ \\ 1,3 Jurusan Fisika Fakultas Sains dan Teknologi UIN Alauddin Makassar \\ Jl. Sultan Alauddin No. 63, Kabupaten Gowa, Sulawesi Selatan. 92113 \\ ${ }^{2}$ Jurusan Kimia Fakultas Sains dan Teknologi UIN Alauddin Makassar \\ Jl. Sultan Alauddin No. 63, Kabupaten Gowa, Sulawesi Selatan. 92113 \\ ${ }^{4}$ Laboratorium Riset Fakultas Sains dan Teknologi UIN Alauddin Makassar \\ Jl. Sultan Alauddin No. 63, Kabupaten Gowa, Sulawesi Selatan. 92113 \\ *E-mail: wadi.phys.dept@uin-alauddin.ac.id
}

\begin{abstract}
Abstrak: Sel surya berbasis sensitiser pewarna (DSSC), telah mendapat perhatian besar untuk diteliti karena mudah untuk disintesis dan fabrikasi, proses pembuatannya memerlukan biaya rendah, dan bahannya melimpah di alam. Pewarna alami yang diekstraksi dari tanaman Indigofera tinctoria dipelajari potensi penggunaannya sebagai sensitiser untuk DSSC (DyeSensitized Solar Cell). Dalam penelitian ini, pewarna diekstraksi dari daun dengan tiga jenis ekstrak yang berbeda yaitu ekstrak segar, kering dan tradisional. TiO2 yang digunakan sebagai bahan aktif diaplikasikan dengan menggunakan metode Doctor Blade. Pengukuran tegangan dan arus dilakukan di luar ruangan di bawah iradiasi matahari. Spektrum UV-Vis pewarna menunjukkan bahwa ketiga sampel menunjukkan jumlah puncak serapan yang berbeda tetapi memiliki panjang gelombang yang sama di wilayah sekitar $644 \mathrm{~nm}$. Hasil penelitian menunjukkan bahwa nilai efisiensi PCE sampel segar, kering dan tradisional adalah masing-masing sebesar $0,6 \% ; 0,3 \% ; 0,1 \%$.
\end{abstract}

Kata Kunci: DSSC, efisiensi, Indigofera tinctoria, pewarna alami, iradiasi matahari

\section{PENDAHULUAN}

$\mathrm{S}^{\mathrm{s}}$ el surya atau sering juga disebut fotovoltaik merupakan instrumen untuk mengubah energi matahari menjadi energi listrik. Sel surya telah berkembang hingga saat ini memasuki generasi ketiga, namun demikian sel surya berbasis silikon masih mendominasi dari total sel atau panel yang beredar di pasaran (Green et al., 2020). Salah satu sel surya generasi ketiga adalah sel surya berbasis ekstrak (dye) dari tumbuhan. Sel surya ini disebut sebagai dye sensitized solar cell (DSSC) yang diperkenalkan pertama kali oleh Gratzel (2001) dengan ekstrak (dye) dapat diperoleh dari berbagai jenis tanaman baik bunga, buah, daun maupun bagian lain yang memiliki zat warna. Dye-sensitized solar cells (DSSCs) memiliki banyak kelebihan dibandingkan dengan sel surya lainnya, yakni biaya produksi yang sangat murah, mudah dalam sintesis dan karakterisasi, tidak bersifat beracun (non-toxic) dan tersedia melimpah di alam. Ekstrak dye atau pigmen yang diperoleh dari tanaman dapat diklasifikasikan menjadi empat bagian, yaitu flavonoids, betalains, karotenoid, dan klorofil (Bhogaita et al., 2016). Penelitian sel surya berbasis DSSC telah dilakukan untuk berbagai jenis ekstrak warna dengan variasi efisiensi rendah hingga nilai PCE di atas $12 \%$ (Green et al., 2017; Green et al., 2020).

Penelitian terbaru menunjukkan bahwa DSSC memiliki nilai effisiensi 11,9 $\pm 0,4 \%$, 
$10,7 \pm 0,4 \%$, dan $8,8 \pm 0,3 \%$, masing-masing untuk sel, mini-modul dan sub-modul (Green et al., 2020). Nilai efisiensi tersebut diperoleh dari ekstrak $d y e$ pada bagian yang berbeda dari tumbuhan. Sel surya berbasis DSSC dengan ekstrak warna dari buah tumbuhan seperti terung ungu (Risnah et al., 2018), pare (Ramdhani et al., 2019), cabe merah (Maming et al., 2017) dan berbagai jenis lainnya (Attanayake et al., 2013). Sedangkan DSSC dengan ekstrak dari daun dan bunga seperti daun ketapang (Putri et al., 2017), daun jarak (Tahir et al., 2018), putri malu (Patunrengi et al., 2019), bunga bougenvil (Hernandez-Martinez et al., 2011) dan yang lainnya (Attanayake et al., 2013).

Sebagai penelitian awal, tujuan utama riset ini adalah untuk mengetahui potensi ekstrak daun tarum untuk digunakan sebagai dye sensitized pada sel surya berbasis DSSC. Sebagaimana diketahui bahwa ekstrak warna daun tarum ini telah lama digunakan oleh suku adat Kajang sebagai bahan pewarna (biru gelap) untuk pakaian adat mereka. Hasil penelitian ini akan menjadi basis data tambahan dalam dye untuk DSSC (Attanayake et al., 2013) dan merupakan penelitian DSCC pertama yang menggunakan tumbuhan tarum.

\section{METODE PENELITIAN}

\section{Ekstraksi Daun Tarum}

Tumbuhan tarum (Indigofera tinctoria) (Gambar 1) yang digunakan dalam penelitian berasal dari daerah adat Kajang Kabupaten Bulukumba. Ekstraksi tumbuhan tarum dibagi menjadi tiga jenis, yaitu ekstrak kering, ekstrak basah (fresh) dan ekstrak tradisional (sampel diambil langsung dari masyarakat Suku Kajang). Ekstraksi basah dan kering menggunakan pelarut etanol dan dilakukan di Laboratorium Kimia Organik UIN Alauddin Makassar.

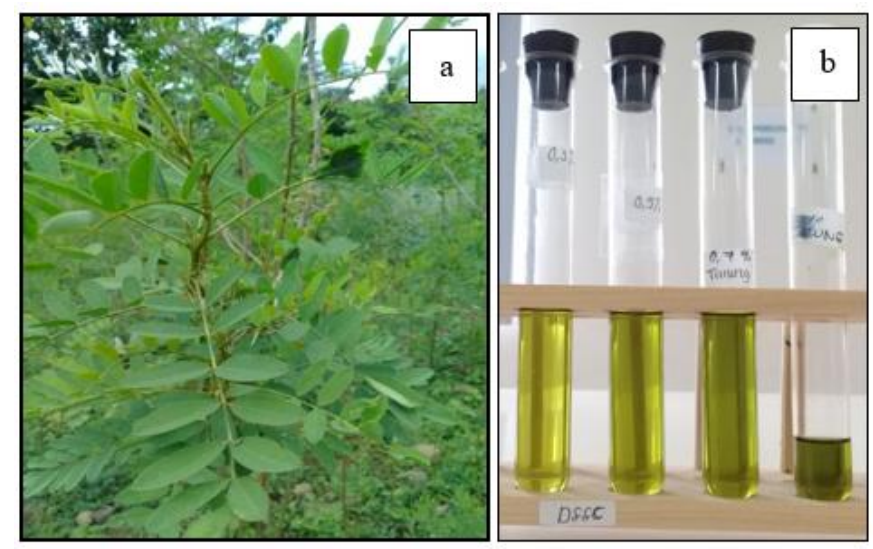

Gambar 1. Tumbuhan tarum (Indigofera tinctoria); a. batang dan b. dye ekstraksi

\section{Fabrikasi Sel Surya}

Kaca semikonduktor yang digunakan adalah kaca yang telah didoping dengan titanium oksida (ITO glass) dengan dimensi $0,7 \mathrm{~cm} \times 2 \mathrm{~cm} \times 2 \mathrm{~cm}$ dan resistansi $7 \Omega-9$ $\Omega$. Sebelum digunakan, kaca ITO dibersihkan dengan aquades. Pasta TiO2 diaplikasikan pada kaca dengan metode doctor blade dengang luasan $1 \mathrm{~cm}$ x $1 \mathrm{~cm}$. Kaca TiO2 yang telah didoping dengan pasta $\mathrm{TiO} 2$ dibiarkan mengering kemudian disintering dengan magnetic stirrer pada suhu $400^{\circ} \mathrm{C}$ selama 30 menit. Pada proses ini pasta $\mathrm{TiO} 2$ akan mengalami perubahan warna dari putih menjadi coklat dan kembali putih. Saat TiO2 telah memutih maka bagian semikonduktor dari sel surya telah jadi dan siap untuk menyerap zat warna (dye). 
Tiga sampel yang telah dipersiapkan diaduk dengan ultrasonik agar menjadi lebih homogen. Kaca ITO dengan pasta $\mathrm{TiO} 2$ yang telah disintering direndam di ketiga sampel dye dan dibiarkan hingga 24 jam. Proses berikutnya adalah membuat bagian konduktif dari sel surya. Bagian ini dibuat dengan menggunakan karbon yang dilapiskan pada kaca ITO, karbon dapat diperoleh dari pensil karbon atau dengan pembakaran. Setelah semua bagian selesai maka kaca ITO yang telah direndam dengan dye (bagian semikonduktor) disatukan dengan dengan kaca ITO yang telah dilapisi karbon (bagian konduktif) menggunakan penjepit sebagaimana yang ditunjukkan pada Gambar 2.

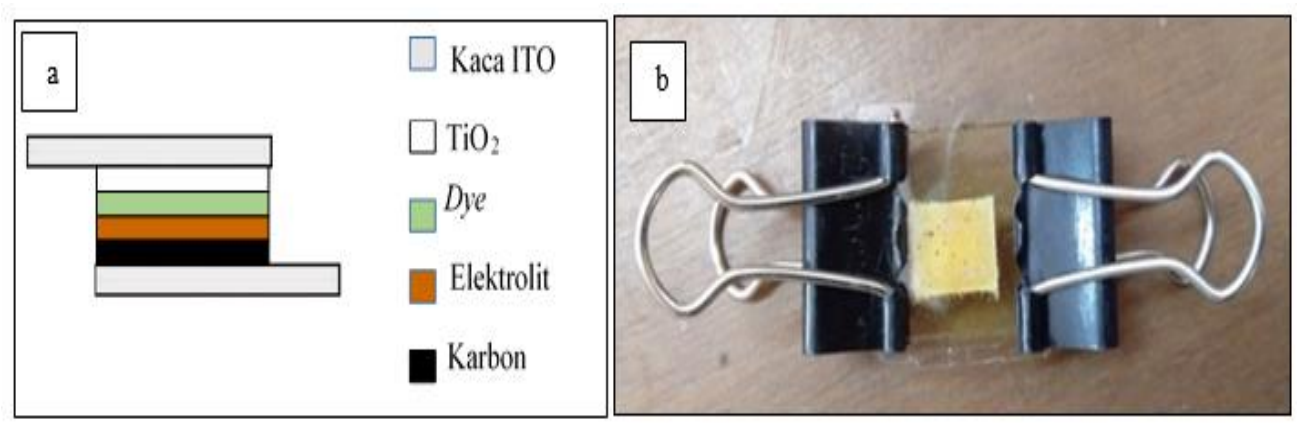

Gambar 2. Sel surya berbasis DSSC dengan dye daun Tarum (Indigofera tinctoria); a. Struktur DSSC dan b. DSSC dye daun Tarum

\section{Pengukuran}

Selama penelitian dilakukan beberapa pengukuran dengan alat intrumen yang sesuai. Pertama, absorbansi dye dengan UV-VIS (UV-2600 Shimadzu) untuk mengetahui panjang gelombang efektif dalam menyerap energi matahari. Kedua, mengukur transmitansi dengan FTIR (Prestige-21 Shimadzu) untuk mengetahui komponen fungsional grup dari dye. Ketiga, SEM-EDX (Joe JSM-6510 LA) untuk mengetahui sistem mikro morfologi dari TiO2 dalam dyes pada kaca ITO. kemudian, XRD (Rigaku Miniflex2) untuk melihat difraksi dan fase $\mathrm{TiO} 2$ yang digunakan dalam penelitian. Selanjutnya pengukuran arus dan tegangan dengan digital multi-meter (UX-369C) secara langsung dengan sinar matahari. Sebuah potensiometer digunakan untuk mengetahui degradasi arus singkat dan tegangan dari sel surya. Pada saat bersamaan digunakan sunlightmeter (Lx 1330B-Lux 200k) untuk mengetahui insiden foton dari sinar matahari. Skema pengukuran penelitian diberikan ditunjukkan pada Gambar 3.

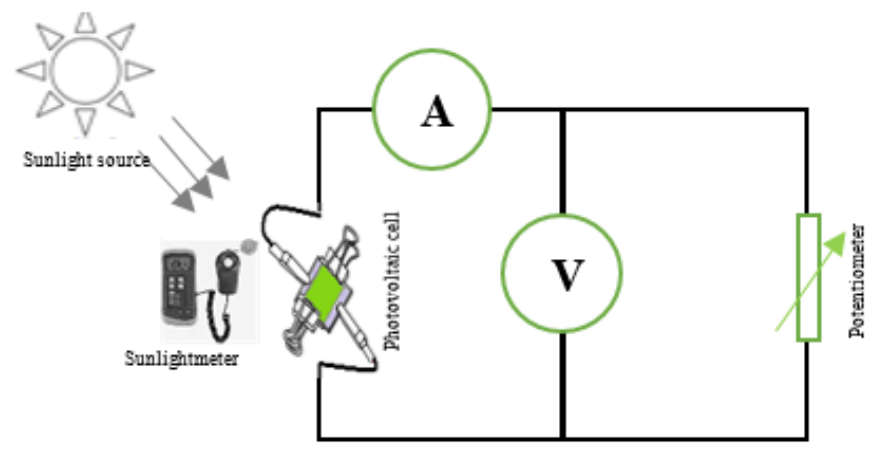

Gambar 3. Skematik pengukuran arus dan tegangan sel surya berbasis DSSC 
Efisiensi sel surya dihitung dengan menggunakan persamaan (1)

$$
\eta=\frac{I_{S C} V_{O C} F F}{P_{\text {in }}}
$$

Variabel Isc, $\mathrm{V}_{\mathrm{oc}}, \mathrm{FF}$, dan $P_{\text {in }}$ pada persamaan (1) merupakan representasi dari arus singkat (photocurrent short-circuit), tegangan terbuka (voltage open circuit), fill factor, dan daya Input (power input).

Perhitungan Fill factor ditunjukkan pada persamaan (2)

$$
F F=\frac{V_{\max } I_{\max }}{V_{o c} I_{s c}}
$$

dimana $V_{\text {max }}$, dan $I_{\max }$ merupakan tegangan dan arus per luasan dengan daya maksimum

\section{HASIL DAN PEMBAHASAN}

\section{Absorbansi Spektrum Dye Daun Tarum (Indigofera tinctoria)}

Absorbansi tiga sampel yang digunakan dalam penelitian diperoleh dari pengukuran UV-Vis. Bagian ini diperlukan untuk melihat sebaran nilai absorpsi optimal dari sampel sehingga nilai panjang gelombang pada titik optimum tersebut dapat diketahui. Puncak-puncak absorbansi dengan panjang gelombang yang bersesuaian akan menentukan proses absorbsi cahaya matahari oleh sel surya. Hasil pengujian UV-Vis disajikan pada Gambar 4.
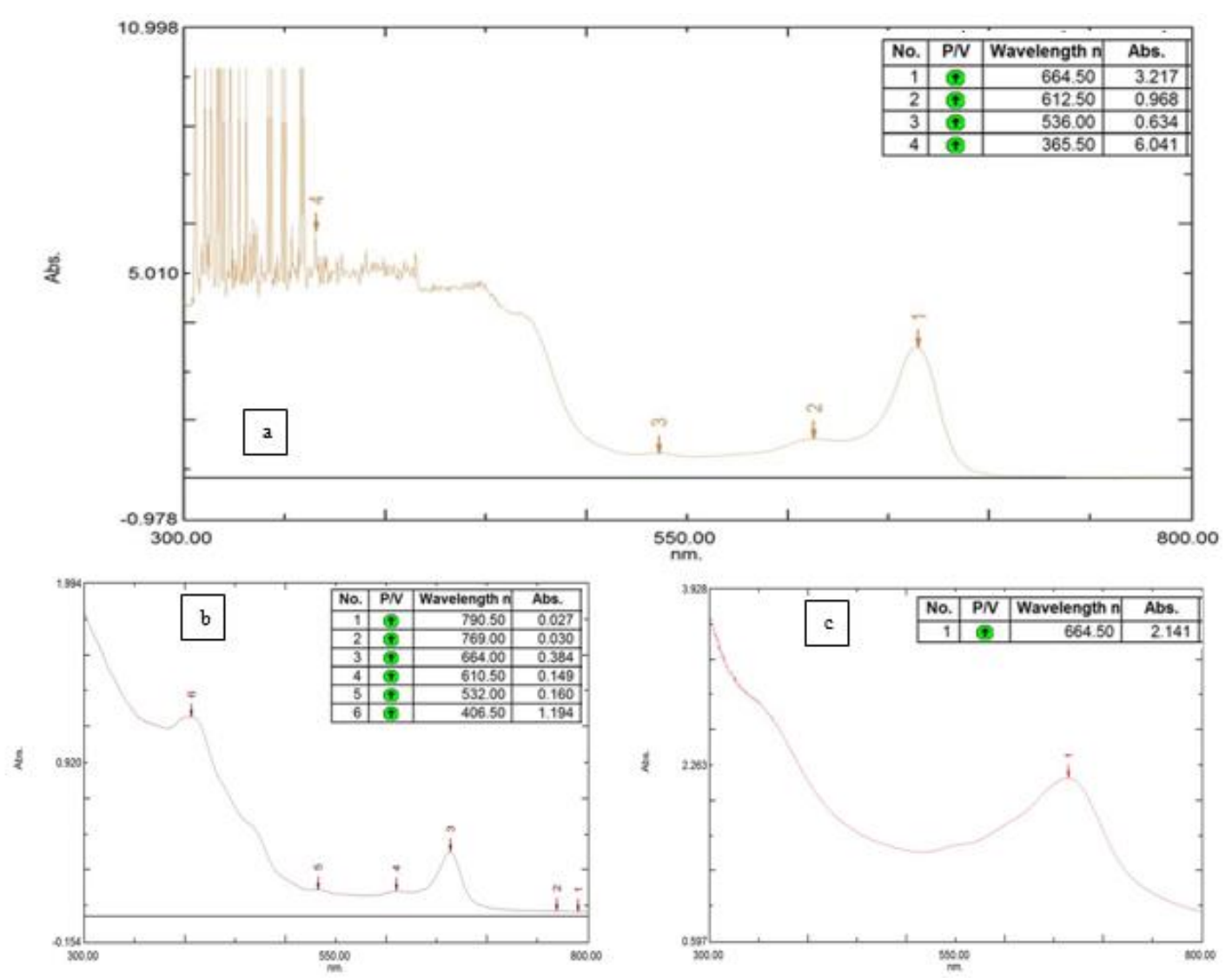

Gambar 4. Spektrum UV-VIS dye daun tarum (Indigofera tinctoria); a. Sampel ekstrak kering, b. Sampel ekstrak segar, dan c. Sampel ekstrak tradisional 
Gambar 4 menunjukkan nilai absorbansi tiga sampel dye yang diperoleh masingmasing dengan ekstrak yang berbeda, yaitu kering, segar dan tradisional. Secara umum semua sampel memberikan puncak absorbansi maksimum pada panjang gelombang yang sama yakni panjang gelombang $664 \mathrm{~nm}$ dengan nilai tertinggi diberikan oleh sampel kering sebesar 3,217 kemudian ekstrak tradisional sebesar 2,141 dan terakhir ekstrak segar sebesar 0,384. Ekstrak kering memberikan hasil yang belum sempurna karena sampel masih membutuhkan pengenceran lanjutan sebelum uji UV-VIS. Namun demikian terdeteksi 4 puncak pada sebaran panjang gelombang $360 \mathrm{~nm}$ hingga $800 \mathrm{~nm}$ dengan nilai maksimum sebesar 6,041 pada panjang gelombang $365 \mathrm{~nm}$. Nilai ini kemungkinan masih akan mengalami pergeseran pada uji berikutnya setelah pengenceran. Sampel segar, meskipun nilai absorbansinya tidak terlalu tinggi namun memiliki nilai yang moderat dengan jumlah puncak yang terdeteksi sebanyak 6 puncak panjang gelombang. Absorbansinya menyebar pada panjang gelombang cahaya tampak mulai dari $406 \mathrm{~nm}$ hingga $800 \mathrm{~nm}$. Sedangkan dye dengan ekstrak yang diambil langsung dari Suku Kajang memberikan nilai absorbansi tunggal pada rentang gelombang cahaya tampak. Meskipun tunggal namum memiliki puncak yang lebih baik dari sampel segar yakni 2,141 pada panjang gelombang 664,50 nm dibandingkan 1,194 pada panjang gelombang 406,50 nm untuk sampel segar. Sebagai penelitian awal, nilai-nilai tersebut sangat signifikan untuk dijadikan acuan pada pengembangan penelitian selanjutnya. Terutama sampel dengan ekstrak kering yang memiliki puncak absorbansi yang belum terdeteksi. Secara teoretis, untuk sel surya berbasis DSSC, semakin banyak puncak panjang gelombang yang terdeteksi maka semakin baik dalam konversi energinya.

Selain uji UV-VIS pada sampel dye, dipelukan juga uji FTIR untuk melihat komponen fungsional kimia yang dikandung oleh dye dan persentase transmitansi yang dimiliki. Hasil uji transmitansi sampel dye ditunjukkan pada Gambar 5.

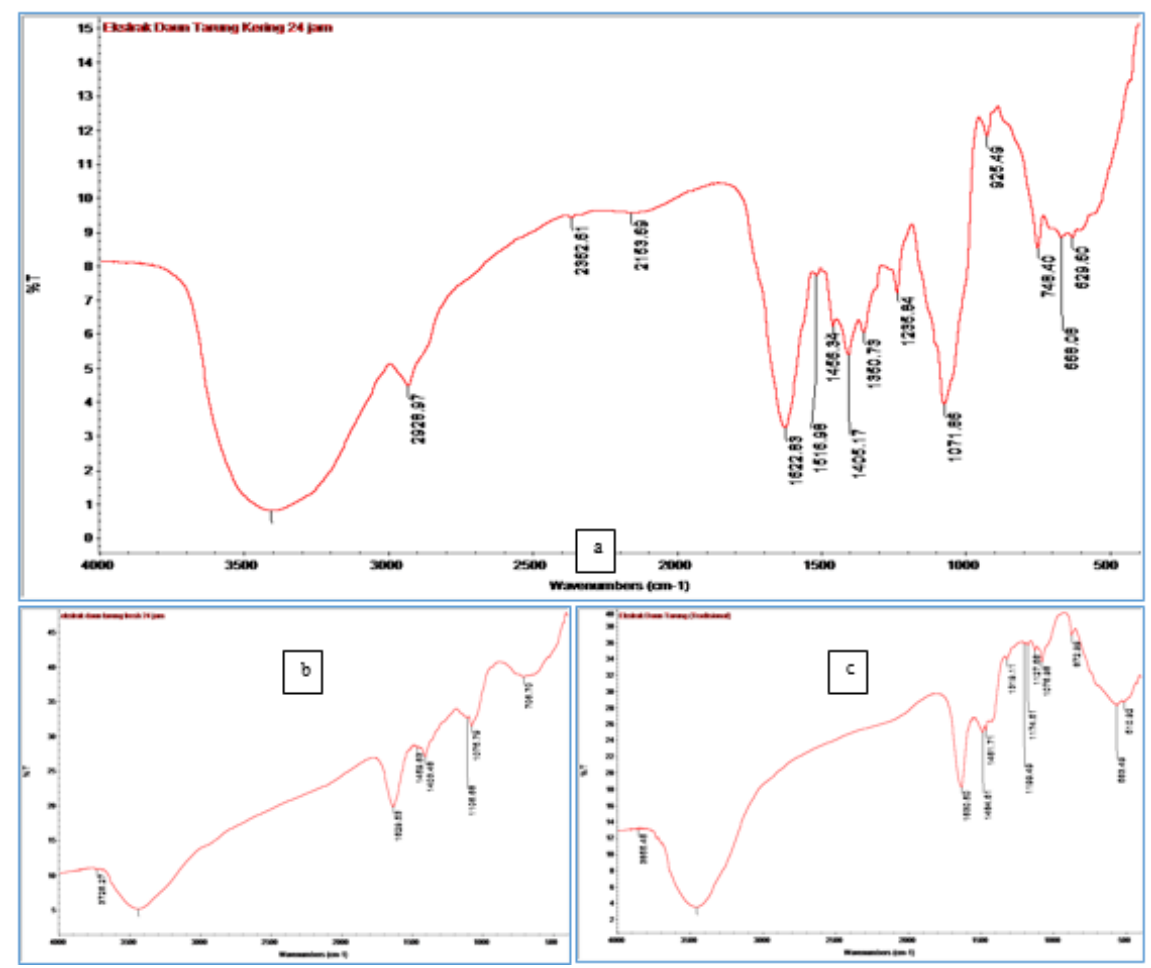

Gambar 5. Transmitansi dari ekstrak tumbuhan tarum (Indigofera tingtoria); a. Ekstrak kering, b. Ekstrak segar dan c. Ekstrak tradisional. 


\section{Difraksi X-ray $\mathrm{TiO}_{2}$}

$\mathrm{TiO}_{2}$ yang digunakan dalam penelitian diuji dengan XRD. Data ini diperlukan untuk melihat fase dan karakteristik dari $\mathrm{TiO}_{2}$ yang akan digunakan sebagai bagian semikonduktor dari DSSC. Secara teori, $\mathrm{TiO}_{2}$ dapat memiliki dua fase yang berbeda yakni; rutile dan anatase. Difraksi TiO2 pada Gambar 6 menunjukkan bahwa TiO2 yang digunakan dalam penelitian berada pada fase anatase. Hasil ini juga menunjukkan karakteristik $\mathrm{TiO} 2$ dalam skala nanometer sedikit heterogen. Dalam aplikasi sel surya berbasis DSSC, fase anatase memberikan kualitas yang lebih baik dari yang lainnya karena secara tidak langsung berpengaruh terhadap efisiensi sel surya.

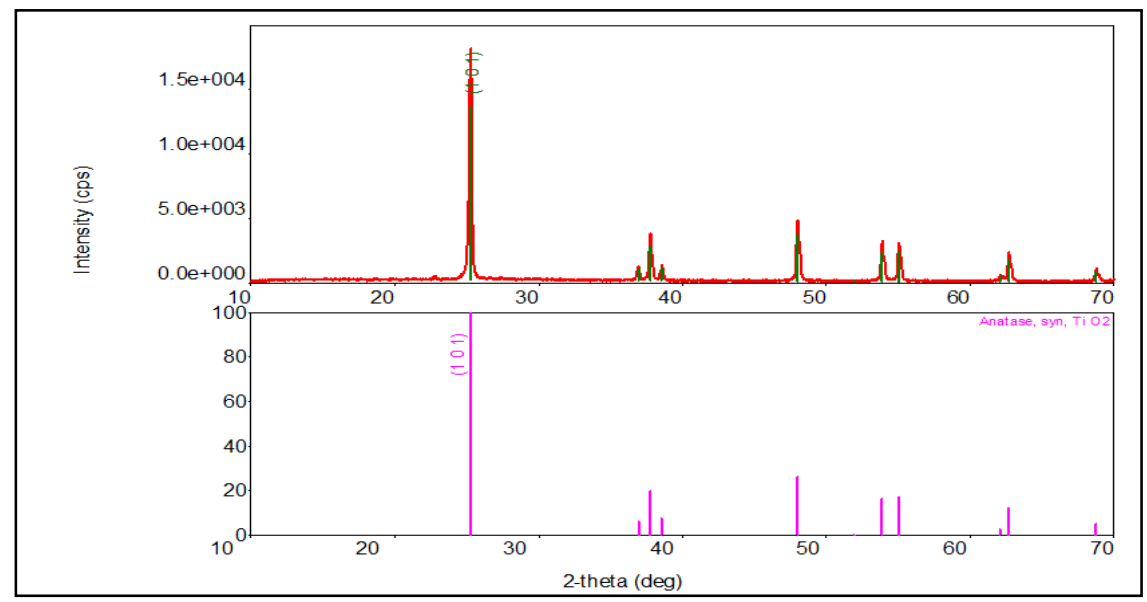

Gambar 6. Karakteristik X-ray dari titanium dioksida

\section{Karakteristik Sel Surya}

Pengukuran arus, Jsc dan tegangan, Voc untuk ketiga DSSC dilakukan langsung di bawah matahari. Hasil yang diperoleh sedikit mengejutkan karena data yang diharapkan ternyata memiliki pergeseran yang unik. Hasil tersebut diperlihatkan pada Gambar 7.

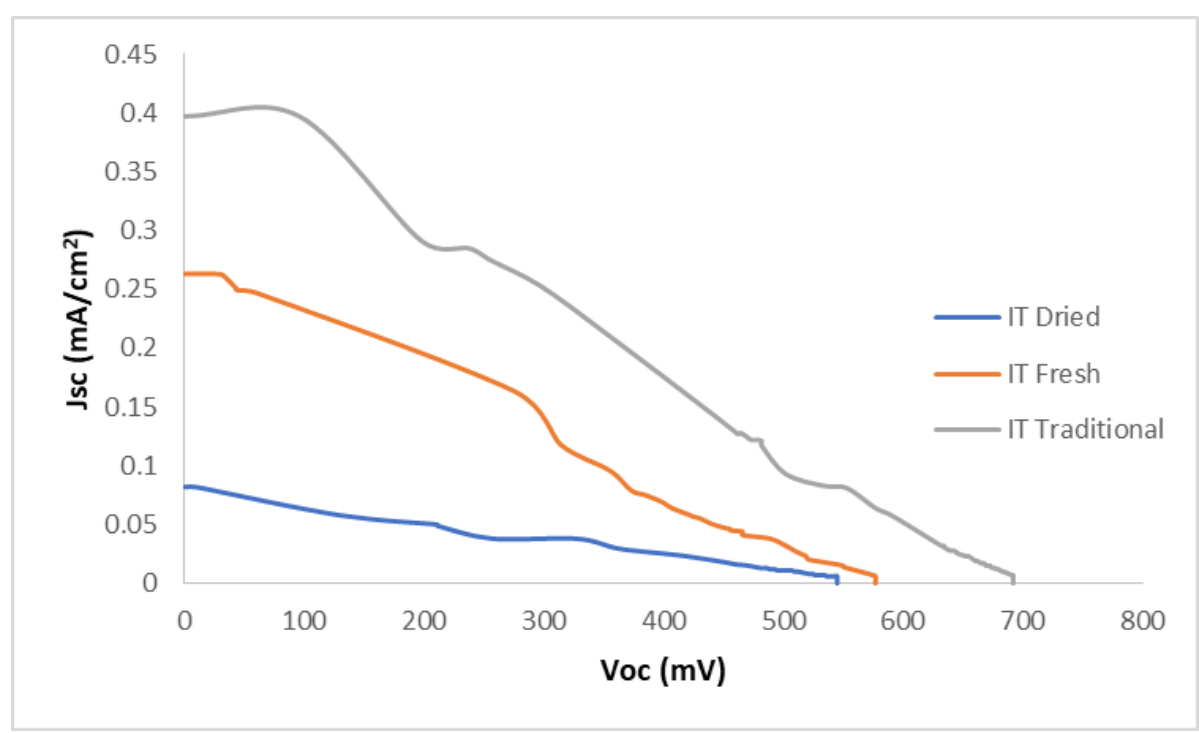

Gambar 7. Kurva I-dari DSSC ekstrak tarum

DSSC sampel kering memberikan nilai arus maksimum sebesar $554 \mathrm{mV}$ dan arus listrik sebesar $0,082 \mathrm{~mA} / \mathrm{cm}^{2}$. Sedangkan DSSC dengan dye ekstrak segar memberikan nilai arus listrik sebesar $0,263 \mathrm{~mA} / \mathrm{cm}^{2}$ dengan tegangan $577 \mathrm{mV}$. Data arus dan tegangan 
tertinggi diberikan oleh DSSC ekstrak tradisional yakni sebesar 0,397 mA/cm ${ }^{2}$ dan 692 $\mathrm{mV}$ secara berurutan. Hal ini kontras dengan hasil UV-VIS yang menunjukkan bahwa absorbansi tertinggi dimiliki oleh sampel tarum kering dengan jumlah puncak yang lebih banyak. Sedangkan DSSC dengan dye tradisional hanya memiliki puncak absorbansi 1 puncak saja. Perlu diketahui bahwa proses ekstraksi secara tradisional dilakukan dalam waktu yang lama sehingga kemungkinan mengalami fermentasi. Hasil ini mengisyaratkan adanya mekanisme yang pelu diteliti lebih lanjut. Karakteristik dari DSSC dapat dilihat pada Tabel 1.

Tabel 1. Efisiensi DSSC sel surya

\begin{tabular}{lccccc}
\hline Jenis Sampel & $\mathbf{V}_{\text {oc }}(\mathbf{m V})$ & $\mathbf{J}_{\mathbf{s c}}\left(\mathrm{mA} / \mathrm{cm}^{2}\right)$ & FF $(\boldsymbol{\%})$ & in $\left(\mathbf{m W} / \mathbf{c m}^{\mathbf{2}}\right)$ & $\mathbf{\eta}(\boldsymbol{\%})$ \\
\hline 'Kering & 0,545 & 0,082 & 0,28 & 12.21083 & 0,101 \\
'Segar & 0,577 & 0,263 & 0,29 & 12.21083 & 0,368 \\
'Tradisional & 0,692 & 0,379 & 0,27 & 12.21083 & 0,615 \\
\hline
\end{tabular}

Tabel 1 menunjukkkan bahwa efisiensi tertinggi dari ketiga DSSC diberikan oleh ekstrak tarum secara tradisional dengan nilai 0,6 \% dari fill factor sebesar 0,27\%. Urutan kedua terbesar diberikan oleh DSSC dengan ekstrak segar sebesar 0,36\% dengan fill factor 0,29\%. DSSC ekstrak kering memberikan hasil efisiensi terkecil yaitu 0,1\% dengan fill factor $0,28 \%$. Hasil ini di luar ekspektasi karena nilai absorbansi ekstrak tradisional tidak terlalu baik dibandingkan dengan absorbansi sampel ekstrak kering dan ekstrak segar sebagaimana yang ditunjukkan pada Gambar 8. Hasil penelitian ini sedikit berbeda dengan beberapa hasil penelitian sebelumnya terhadap beberapa jenis ekstrak tumbuhan seperti kulit terong ungu (Risnah et al., 2018), daun buah pare (Ramadhani et al., 2019), alga hijau (Lämmermann et al., 2018), serta bawang merah, cabe merah, dan Bayam (Ammar et al., 2019).

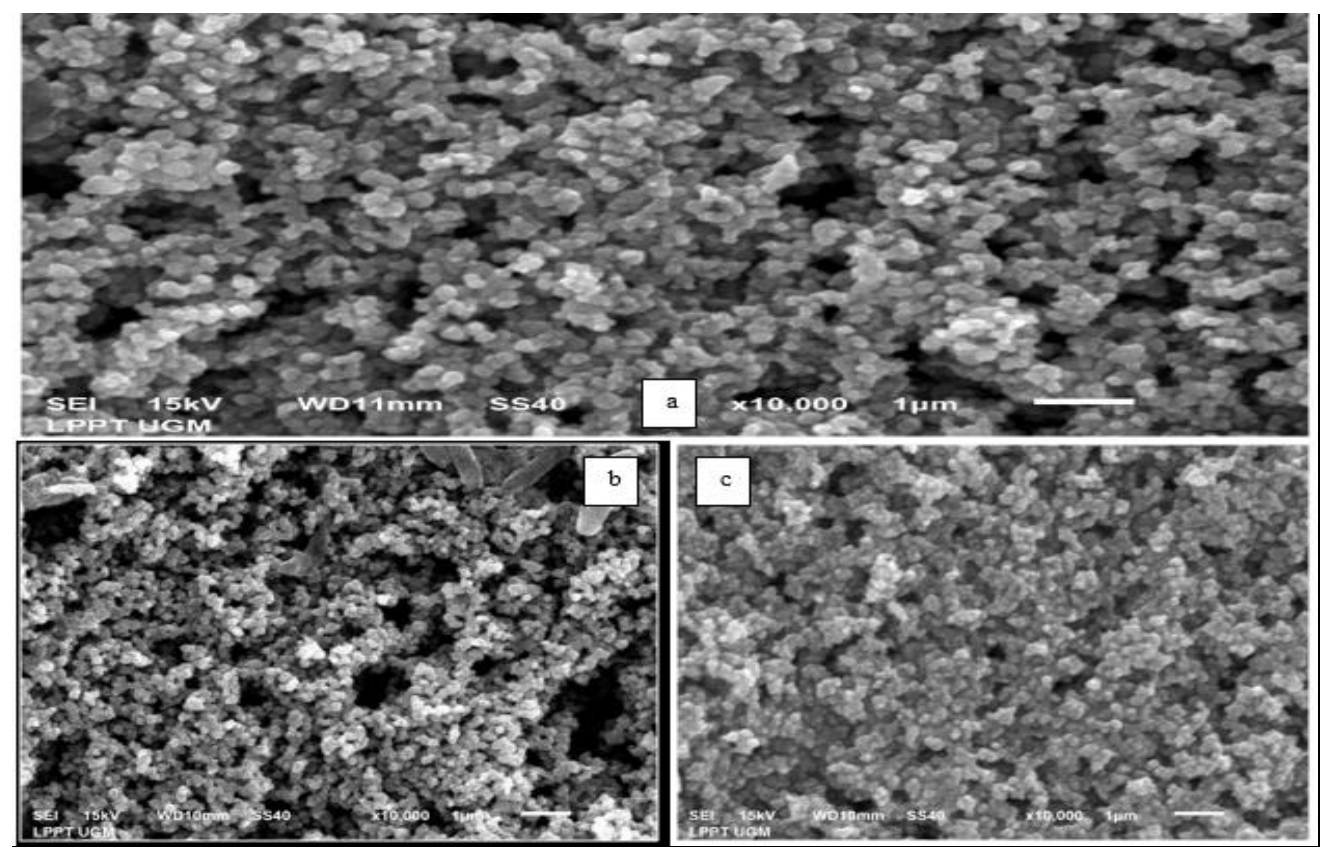

Gambar 8. Morfologi sel surya; a. IT Kering, b. IT segar, dan c. IT tradisional

Gambar 8 menunjukkan karakteristik morfologi dari TiO2 yang digunakan dalam penelitian dan dye. Secara umum sebaran $\mathrm{TiO} 2$ yang telah direndam dye memiliki karakter sama untuk ketiga sampel DSSC. Namun DSSC dengan ekstrak tradisional lebih 
homogen dan lebih teratur jarak antar partikelnya sehingga tidak memiliki lubang (hole) sebagaimana dua sampel yang lain. Morfologi ini menjadi alasan mengapa nilai efisiensi DSSC ekstrak tradisional lebih tinggi dari yang lainnya.

\section{KESIMPULAN}

Penelitian awal pengembangan DSSC dari ekstrak tumbuhan tarum (Indigofera tingtoria) telah dilakukan. Berdasarkan hasil yang diperoleh dapat disimpulkan bahwa ketiga jenis ekstrak sampel memberikan nilai yang berbeda. Nilai efisiensi tertinggi diberikan oleh ekstrak tradisional sebesar 0,6\% kemudian ekstrak segar dan kering masing-masing sebesar $0,3 \%$ dan $0,1 \%$. Absorbansi ekstrak daun tarum memiliki beberapa puncak yang tersebar pada panjang gelombang cahaya tampak dengan nilai optimum berada pada panjang gelombang $664,50 \mathrm{~nm}$. Sebagai penelitian awal maka datadata tersebut sangat bermanfaat untuk penelitian lebih lanjut.

\section{DAFTAR PUSTAKA}

Ammar, A. M., H. S. H. Mohamed., M. M. K. Yousef., G. M. Abdel-hafez., A. S. Hassanien., \& A. S. G. Khalil. (2019). Dye-Sensitized Solar Cells ( DSSCs ) Based on extracted natural dyes. Journal of Nanomaterials, 2019, 1-10. Doi. 10.1155/2019/1867271.

Attanayake, I., C. De Silva., B. A. J. K. Premachandra., A. A. P. De Alwis., \& G. K. R. Senadheera. (2013). Dye-sensitized solar cells: Using over 100 natural dyes as sensitizers. 2013 AIChE Annual Meeting. 5 November 2013.

Bhogaita, M., A. D. Shukla., \& R. P. Nalini. (2016). Recent advances in hybrid solar cells based on natural dye extracts from Indian plant pigment as sensitizers. Sol. Energy, 137, 212-224. Doi. 10.1016/j.solener.2016.08.003.

Grätzel, M. (2001). Photoelectrochemical cells. Nature, 414, 338-344.

Green, M. A., Y. Hishikawa., W. Warta., E. D. Dunlop., D. H. Levi., J. Hohl-Ebinger., \& A. W. H. HoBaillie. (2017). Solar cell efficiency tables (version 50). Prog. Photovoltaics Res. Appl, 25(7): 668676. Doi. 10.1002/pip. 2909.

Green, M. A.., E. D. Dunlop., J. Hohl-Ebinger., M. Yoshita., N. Kopidakis, \& A. W. Y. Ho-Baillie. (2020). Solar cell efficiency tables (Version 55). Prog. Photovoltaics Res. Appl, 28(1), 3-15, 2020. Doi. 10.1002/pip.3228.

Hernandez-Martinez, A. R., M. Estevez., S. Vargas., F. Quintanilla., \& R. Rodriguez. (2011). New dyesensitized solar cells obtained from extracted bracts of Bougainvillea glabra and Spectabilis betalain pigments by different purification processes. Int. J. Mol. Sci, 12(9), 5565-5576. Doi. 10.3390/ijms12095565.

Lämmermann, N., F. Schmid-Michels., A. Weißmann., L. Wobbe., A. Hütten., \& O. Kruse. (2018). Extremely robust photocurrent generation of titanium dioxide photoanodes bio-sensitized with recombinant microalgal light- harvesting proteins. Scientific Reports, 9, 2109, 1-9. Doi. 10.1038/s41598-019-39344-6.

Maming, M. S., A. Aisyah., S. Suriani., \& I. Iswadi. (2017). Photosenzitizer dari fraksi metanol: N-Heksana buah cabe merah (Capsiccum annum L.). Al-Kimia, 5(1), 31-38. Doi. 10.24252/al-kimia.v5i1.2846.

Patunrengi, I. I., A. Aisyah., S. Sahara., N. Fuadi., Muarif., \& Ardian. (2019). A new study of dye-sensitized solar cell from the extract of leaf, fruit, and mix of Mimosa pudica Linn. 1st International Conference on Science and Technology, ICOST 2019. 2-3 Mei 2019. Makassar: Fakultas Sains \& Teknologi UIN Alauddin Makassar. Doi. 10.4108/eai.2-5-2019.2284699.

Putri, K. A., A. Aisyah., S. Suriani., \& I. Iswadi. (2017). Pengaruh kandungan senyawa pada ekstrak daun ketapang n-heksan, etil asetat, metanol dan campuran terhadap nilai efisiensi dye sensitized solar cell (DSSC). Al-Kimia, 5(2): 170-180. Doi. 10.24252/al-kimia.v5i2.3856.

Ramadhani, I., W. Febriya., S. Suriani., A. Aisyah., \& I. Iswadi. (2019). A natural dye-sensitized from pare (Bitter gourd) leaves extracts for Dye-Sensitized Solar Cell (Dssc). Al-Kimia, 7(1), 17-24. Doi. 10.24252/AL-KIMIA.V7I1.6309.

Risnah, I. A., A. Aisyah., I. Iswadi., \& J. Saokani. (2018). The Photosensitizer from the basic dye extract 
17 Jurnal Teknosains, Volume 15, Nomor 1, Januari-April 2021, hlm. 9-17

of the skin fruit of eggplant (Solanum melongena L.). Al-Kimia 6(1), 1-9. Doi. 10.24252/ALKIMIA.V6I1.4826.

Tahir, D., W. Satriani., P. L. Gareso., \& B. Abdullah. (2018). Dye sensitized solar cell (DSSC) with natural dyes extracted from jatropha leaves and purple Chrysanthemum flowers as sensitizer. Journal of Physics: Conference Series, 979(1), 1-7. Doi. 10.1088/1742-6596/979/1/012056. 